\title{
When and how to test for $C-M Y C$ in aggressive B cell lymphomas
}

\author{
Sylvia Hoeller • Alexandar Tzankov • Frank Stenner • \\ Stephan Dirnhofer
}

Received: 2 July 2014 / Accepted: 29 August 2014 /Published online: 16 September 2014

(C) Springer-Verlag Berlin Heidelberg 2014

\begin{abstract}
C-M Y C(M Y C)$ is a regulator gene that plays an important role in cell cycle progression, apoptosis, and cellular transformation. It is believed to regulate expression of up to $15 \%$ of all human genes. In recent years, $C-M Y C$ has been extensively studied in blastic B cell lymphomas, and currently $C-M Y C$ is regarded not only as a diagnostic tool, but also a promising prognostic biomarker. $C-M Y C$ testing is therefore no longer simply a confirmational analysis for Burkitt's lymphoma, but also provides important information on prognosis and risk stratification of diffuse large B cell lymphoma patients. This review outlines our approach to integrate this new role of $C-M Y C$ in a convenient way in routine diagnostics and discusses the application of different techniques such as immunohistochemistry and FISH for C-MYC testing.
\end{abstract}

Keywords c-myc $\cdot C-M Y C \cdot$ DLBCL $\cdot$ Burkitt lymphoma $\cdot$ Immunohistochemistry $\cdot$ FISH $\cdot$ Prognosis $\cdot$ Double-hit score

\section{Introduction}

The $C-M Y C$ gene was identified more than 20 years ago as the cellular homolog of the retroviral $v-m y c$ oncogene [1-3]. Since then, its protein function, expression, and the epidemiology of its gene alterations have been intensively studied. $C$ $M Y C$ has been shown to be a regulator gene that codes for a transcription factor, a multifunctional nuclear phosphoprotein that plays a role in cell cycle progression, apoptosis, and

S. Hoeller $(\bowtie) \cdot$ A. Tzankov $\cdot$ S. Dirnhofer Institute of Pathology, University Hospital Basel, University of Basel, Schoenbeinstr. 40, 4031 Basel, Switzerland

e-mail: sylvia.hoeller@usb.ch

\section{F. Stenner}

Division of Oncology, Department of Internal Medicine,

University Hospital, Basel, Switzerland cellular transformation, and is believed to regulate expression of up to $15 \%$ of all human genes [4]. Recent work suggests that c-myc is a TATA-Box-binding factor that regulates all genes transcribed by RNA-polymerase 2, meaning that c-myc is acting as a transcriptional amplifier rather than as a transcription factor per se [5]. Importantly, $C-M Y C$ plays a major role in the pathogenesis of malignant neoplasms, particularly lymphomas, and its gene is recurrently deregulated either by rearrangements, amplifications, or mutations [4]. Over $90 \%$ of Burkitt's lymphomas (BL) carry a $\mathrm{t}(8 ; 14)$ or, less commonly, a $\mathrm{t}(2 ; 8), \mathrm{t}(8 ; 22)$, or $\mathrm{t}(3 ; 8)[6,7]$, juxtaposing the $C-M Y C$ gene to the immunoglobulin heavy chain, or the light chain gene. However, 5-14 \% of diffuse large B cell lymphomas (DLBCLs) also display translocations involving C-MYC [8-10], occasionally leading to a diagnostic challenge since aggressive lymphomas with $C-M Y C$ rearrangement can be either (i) BL, (ii) B cell lymphomas, or unclassifiable, with features intermediate between DLBCL and BL (BCL-U, iBL/ DLBCL), or (iii) DLBCL not otherwise specified. The exact classification relies on the interpretation of clinical data, morphology, immunohistochemical profile, and molecular genetics.

In recent years, great efforts have been made to subclassify the heterogeneous group of DLBCL. Gene expression profiling (GEP) stratified DLBCL into biologically and prognostically relevant subtypes based on cell-of-origin (COO) gene signatures, with the activated $\mathrm{B}$ cell type being associated with an inferior outcome compared with the germinal center B cell type [11-13]. However, GEP is not yet easily accomplished on formalin-fixed paraffin-embedded (FFPE) tissues as it requires considerably bioinformatics expertise and is available in only a few clinical laboratories, limiting its impact on daily clinical diagnostic use [13]. The translation of complex GEP predictors into immunohistochemical algorithms that assign a COO subtype on the basis of expression of subtype-related proteins has been difficult, 
and the prognostic and predictive accuracies of such algorithms have been shown to be quite variable [14-23]. Recently, c-myc protein overexpression and $C-M Y C$ gene translocations in DLBCL proved to be a better predictor of prognosis than COO in patients with DLBCL, and not only in the context of double- or triple-hit lymphomas [8, 13, 24-28]. Thus, $C-M Y C / c-m y c$ testing is no longer simply a confirmational analysis for $\mathrm{BL}$, but also provides important information regarding prognosis and risk stratification of DLBCL patients. In light of these emerging findings, practicing hematopathologists are confronted with the following questions:

1. Should any blastic B cell lymphoma be analyzed for $C$ MYC aberrations?

2. When is it appropriate to use immunohistochemistry for c-myc, and when is it more appropriate to perform $C$ MYC FISH?

3. If the above analyses are performed, how should the results be interpreted?

\section{Burkitt's lymphoma}

BL is an aggressive, but potentially curable, disease. The translocation involving $C-M Y C$ is highly characteristic of $\mathrm{BL}$, but not specific; up to $10 \%$ of BL patients may lack demonstrable $C-M Y C$ translocation by FISH. Neither morphology, genetics, or immunophenotyping can be used as the sole diagnostic criterion for BL, which instead requires a combination of results from different techniques, including clinical presentation (such as age and localization) [29]. This can complicate diagnosis, and the demonstration of a $C-M Y C$ translocation can assist in attributing a given lymphoma to the corresponding diagnostic entity. Most cases have translocation of C-MYC (8q24) to the immunoglobulin heavy chain (14q32) or, less commonly, to the lambda (22q11) or kappa (2p12) light chain loci [29]. Since FISH is a sophisticated technique requiring significant equipment and expertise, immunohistochemistry offers the advantage of being easier to perform and at lower costs. In 2010, Ruzinova et al. [30] described for the first time an antibody detecting c-myc in FFPE that could also serve as a screening tool to identify lymphomas with potential C-MYC translocations. However, it is not clear when to start with a "positive result" and when to perform consecutive FISH analysis. The literature provides a range of different cut-offs starting from $>50 \%$ positive tumor cell nuclei [31] up to $90-100 \%$ positive tumor cell nuclei [25], which can be explained by the different weighting of the specificity and sensitivity of the respective cut-off scores (Fig. 1). For our biological understanding, the number of positive nuclei should be rather high in BL (since the $C$ -
MYC translocation is supposed to be the driver mutation, and typically BL contains only a few tumor-infiltrating $\mathrm{T}$ cells). Interestingly, most of the known point mutations of $C-M Y C$ in BL cluster in the N-terminal domain (between p. 1 and 170) [32], a protein region to which the commerciallyavailable c-myc antibody Y69 also binds. Thus, given the frequency of (ongoing) C-MYC mutations in $\mathrm{BL}$, it would not be surprising to find immunohistochemically negative $\mathrm{BL}$ cases with a detectable $C-M Y C$ rearrangement by FISH, since a given point mutation may abrogate the binding site of the antibody and, therefore, hide the protein from detection, analogous to "bcl2 negative," yet $\mathrm{t}(14 ; 18)$ positive, follicular lymphomas [33].

The recommended algorithm for BL (Table 1) is as follows:

- If morphology, immunohistochemistry $\left(\mathrm{CD} 20^{+} / \mathrm{CD}^{-} /\right.$ $\mathrm{CD}^{+} 0^{+} / \mathrm{CyclinD}^{-} / \mathrm{BCL}^{-} / \mathrm{BCL}^{+} / \mathrm{CD} 44^{-} / \mathrm{CD} 38^{+} / \mathrm{Ki} 67>$ $95 \%$ ), and clinical context (age and topography) are in line with BL, and c-myc is immunohistochemically detectable in $>95 \%$ of tumor cells, diagnosis of BL can be made without FISH confirmation. This phenotype is highly characteristic and allows also the exclusion of blastic mantle cell lymphoma. Importantly, $\mathrm{CD} 10^{-}$and bcl $2+\mathrm{BL}$ do not exist.

- All cases expressing c-myc in lower percentages should be subjected to FISH analysis for C-MYC (first line breakapart probe and, if negative, double-fusion probe in a second run). If both FISH examinations suggest a nonrearranged $C-M Y C$ gene, then aggressive "Burkitt's-like" lymphomas (BCL-U) with recurrent 11q aberrations [34] or with c-myc activation due to miRNA-34 downregulation [35] should be considered.

- If everything is in line with BL but c-myc immunohistochemistry is completely negative, $C-M Y C$ point mutations, which truncate the protein, should be considered, and $C$-MYC FISH should be performed. If $C-M Y C$ FISH is also negative in such a case, it should be classified as BCL-U according to the suggestion of Salaverria et al. [34].

\section{Diffuse large B cell lymphoma, not otherwise specified}

In DLBCL, the situation is more complex. In unselected DLBCL series, rearrangements of the $C-M Y C$ gene were discovered in approximately $10 \%$ of cases [9, 10, 36-39]. Of these, 20 to $30 \%$ may have an additional break in the $B C L 2-$ and/or BCL6 genes [40-42], fulfilling the criteria of socalled genotypic double-hit lymphomas.

Recent data point to the additive prognostic information obtained from FISH for individual risk estimation, since all types of $C-M Y C$ rearrangements, "IG and non-IG," were 


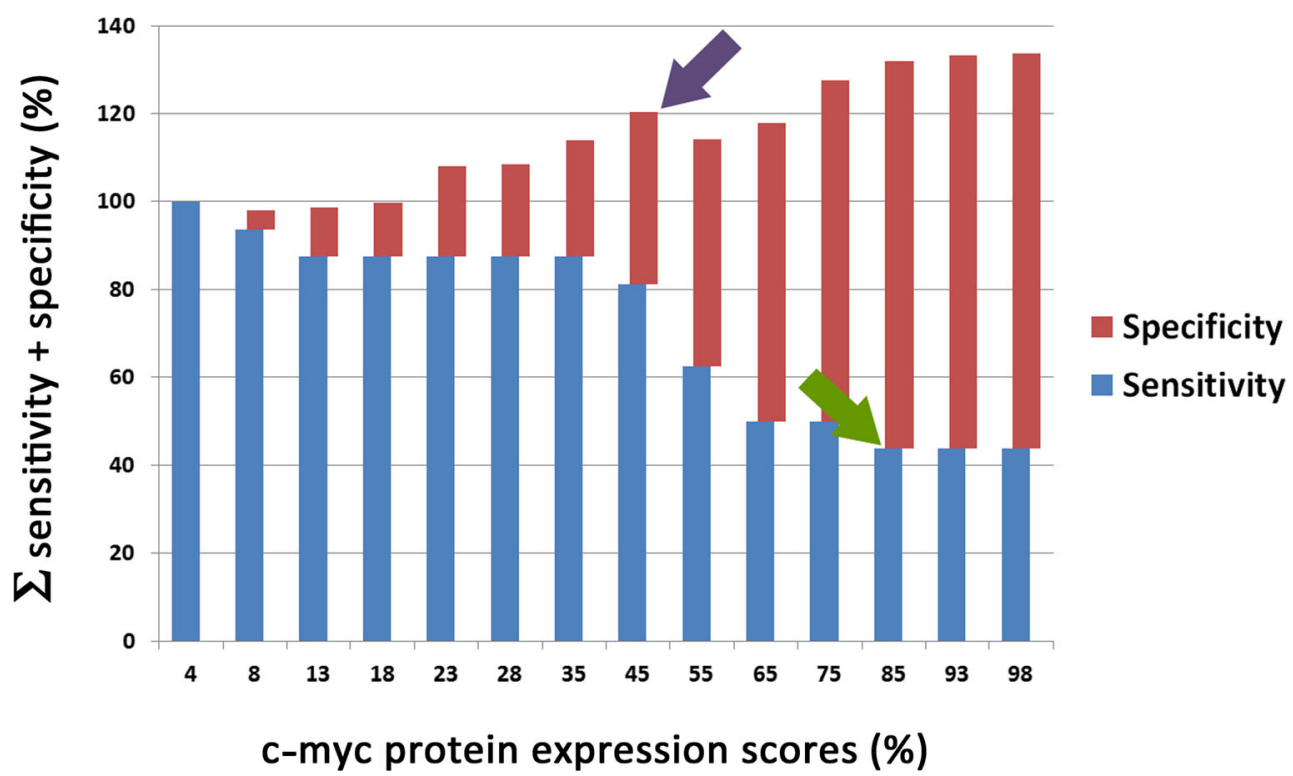

Fig. 1 Specificity and sensitivity of different c-myc cut-off scores to predict $C-M Y C$ rearrangements. Increasing specificity, but decreasing sensitivity, of different c-myc immunohistochemical cut-off scores to predict $C-M Y C$ gene rearrangements. Ideally, the sum of specificity and sensitivity would be $200 \%$. Cut-off scores around $95 \%$ have a specificity and sensitivity sum of approximately $135 \%$ and are nearest to ideal in that they are very specific but less sensitive. Note that to the right of the cut-off score of $85 \%$ (green arrow) there is a plateau with respect to sensitivity, indicating that beyond this cut-off, the number of falsenegative cases does not increase, but the maximum specificity is reached (maximum amount of true positive cases) at cut-off scores around $95 \%$. Note that to the right of the cut-off score of $40 \%$ (purple arrow) there is a volatile rise in specificity of c-myc immunohistochemistry to predict $C$ $M Y C$ rearrangements without significant loss of sensitivity associated with poorer disease-specific survival in DLBCL [8]. Several studies demonstrated that immunohistochemical staining for c-myc is a good screening tool, since almost $50 \%$ of cases expressing c-myc in over $90 \%$ of tumor cells are also $C-M Y C$ rearranged. There are also cases (approximately $10 \%$ ) that present without (or without relevant) immunohistochemically stainable c-myc despite bearing a rearrangements $[26,27,43]$. The significance of the latter set of cases (C-MYC FISH-positive, but immunohistochemically negative) is unclear; additional studies, including identification of the $C-M Y C$ translocation partners and sequencing for epitope-abrogating point mutations, will be required to further clarify the biological and clinical significance of these subsets [44]. Importantly, recent evidence shows that rearrangements with low c-myc protein expression might be associated with a better prognosis than the presence of rearrangements or high c-myc expression [8], pointing towards the relevance of c-myc protein overexpression. From the technical point of view, it should be stressed that, analogously to BL, it is essential not to use only the break-apart probe or the double-fusion probe in an isolated manner for the detection of $C-M Y C$ rearrangements, since a subset of translocations may be missed by either probe $[8,45]$. The best practical way is to use the double-fusion probe, if in a first attempt the break-apart probe is negative (see below).

The puzzling role of c-myc overexpression in DLBCL can be sought in the fact that, not only the $C-M Y C$ translocation itself, but particularly the deregulation of c-myc by other mechanisms, can give rise to a BL-like GEP pattern [7]; in the group of lymphomas showing typical gene expression profiles of BL, there were cases without any detectable translocation of $C-M Y C$ ( 4 cases of 38). These findings were confirmed by recent studies showing significantly elevated c-myc protein expression in tumors lacking translocations of the $C$-MYC gene $[24,43,46]$. Alternative mechanisms equally presaging upregulation of $C-M Y C$ have been suggested. miRNAs regulating c-myc expression have been described and, accordingly, miRNA profiles show differences in $C$ $M Y C$-rearranged and non-rearranged $\mathrm{BL}[35,47]$, and also in DLBCL [48]. Amplifications of C-MYC (encountered in $<1 \%$ of DLBCL) have also been shown to be associated with c-myc overexpression and poorer prognosis $[49,50]$. Therefore, given the important role of the c-myc protein, which regulates a substantial number of genes, and possible alternative causes (other than C-MYC gene rearrangements) of c-myc overexpression, it is not surprising that protein overexpression of c-myc, regardless of gene translocations, plays an important prognostic role in DLBCL. Moreover, DLBCL with immunohistochemical c-myc overexpression, particularly in combination with bcl2 positivity (referred as phenotypic double-hit score (DHS) positive cases), follows an aggressive clinical course with adverse prognosis [13, $24,26,28,43]$. The adverse effect of c-myc deregulation (overexpression on protein level, mRNA level, or 
Table 1 The Basel algorithm in diffusely growing blastic lymphomas

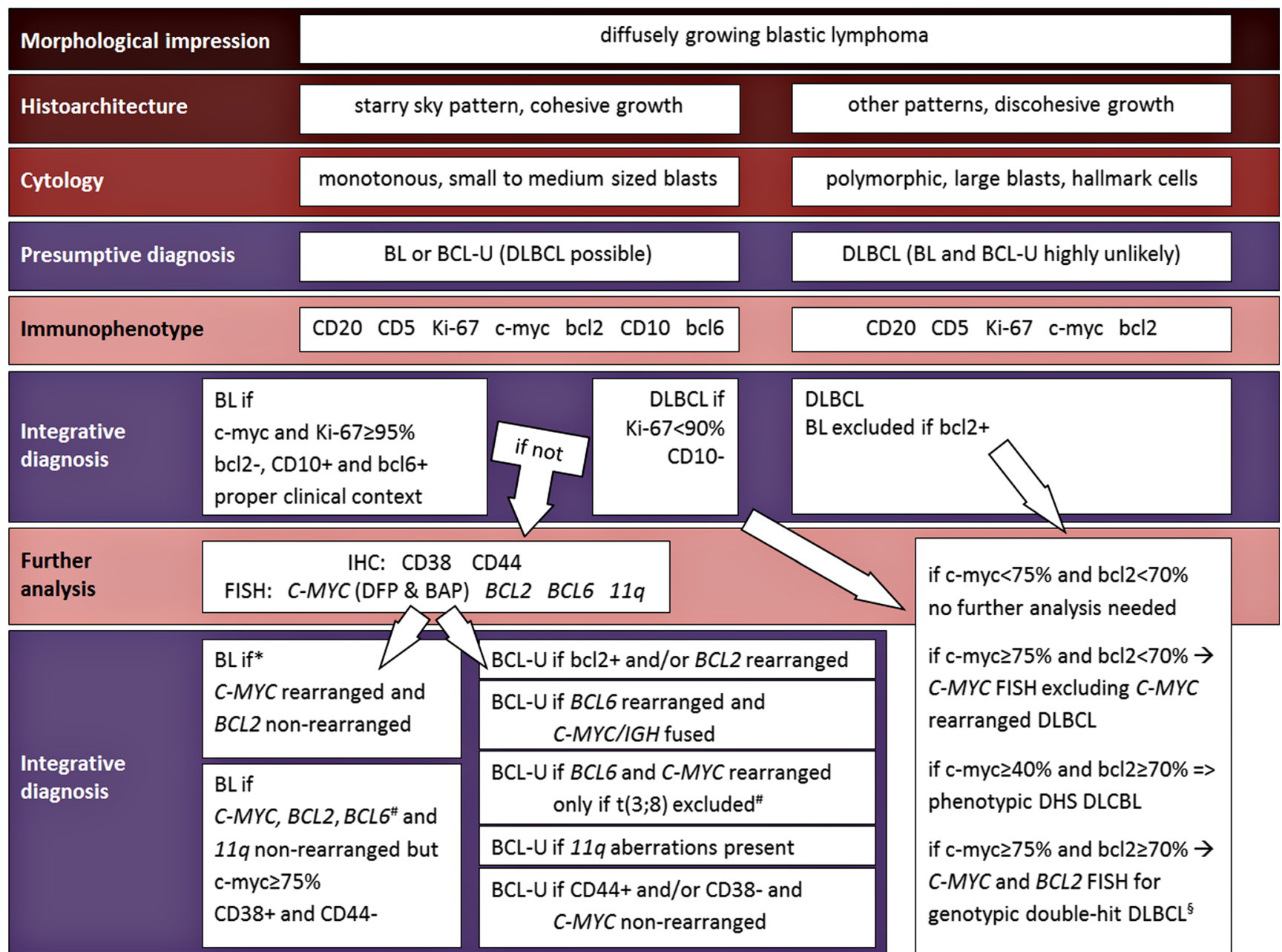

The proposed workflow model reflects our approach based on integration of the diagnostic criteria of the WHO 2008 classification and most recent research data, although we acknowledge the scarcity in the literature of data regarding the step describing how to deal with CD10-negative small blastic ("atypical Burkitt-like") DLBCL. Diagnostic cut-off levels of immunohistochemical markers were chosen as follows: $\geq 7.5 \%$ for CD10 [64] and positive/negative for CD44 and CD38 [65]

*Consider truncating $C-M Y C$ mutations in c-myc-negative, but FISH-positive, cases

${ }^{\#} B C L 6$ breaks in cases positive for $C-M Y C / I G H$ fusion precludes diagnosis of BL. In instances with $B C L 6$ and $C$-MYC breaks, t( $\left.3 ; 8\right)$ juxtaposing $C$ $M Y C$ and $B C L 6$ must be excluded since such cases are still compatible with BL

$\S$ According to the WHO 2008 classification, genotypic double-hit DLBCL can be classified as BCL-U

rearrangement) was recently confirmed by a meta-analysis of 24 eligible studies comprised of 4,662 patients who did or did not have Rituximab as part of their chemotherapy regimen [51].

There are still many open questions before this knowledge can be applied in daily clinical practice:

1. Is it recommended that all DLBCL be stained for c-myc (and bcl2)?

2. What are the best prognostic cut-off values for c-myc (and bcl2)?

3. Which are the most relevant immunohistochemical cutoff values predicting $C-M Y C$ breaks in DLBCL?

4. When should $C-M Y C$ FISH be performed? (a) Considering recent data from a large, independent patient cohort [24, 25, 28, 43], we recommend staining of all DLBCL for both bcl2 and c-myc at initial diagnosis (Table 1) [52]. As is true for all immunohistochemically assessed biomarkers, specific attention should be paid to proper fixation, robust staining protocols, and precise counting. The information gained from these stainings can help physicians to stratify the cohort of DLBCL patients into patients with superior and inferior prognosis even though we acknowledge that a subgroup of high-risk patients such as elderly patients or patients with significant comorbidities cannot be treated more aggressively (see discussion below).

(b) In the literature, different prognostic cut-off scores for cmyc and bcl 2 were reported, varying from $\geq 10 \%$ [26], 
$\geq 40 \%[24,28,43,44]$ and $>75 \%$ [8] for c-myc, and $\geq 30 \%$ [44], $\geq 50 \%[26,43]$, and $\geq 70 \%[24,28]$ for bcl 2 .

The cut-offs most often used (and reproduced) for prognostication are $\geq 40 \%$ for c-myc and $\geq 50$ or $\geq 70 \%$ for bcl2.

(c) The question of the most relevant immunohistochemical values for c-myc is difficult to answer, since there are both immunohistochemically negative/FISH positive cases and immunohistochemically positive/FISH negative cases. The optimal immunohistochemical cut-off for c-myc to predict FISH-positive cases is unclear, and data in the literature vary widely between a minimum of $\geq 30 \%$ [26], $\geq 50 \%$ [31], $\geq 80 \%$ [25], and $>95 \%$ [8], although lower percentages also exist, e.g., 5 and $19 \%$ [26]. This difference is obviously due to the different weighting of the specificity and sensitivity of the respective cut-off scores (Fig. 1).

In our series of 432 cases, a positive predictive value of c-myc protein overexpression to detect $C-M Y C$ rearranged cases was $60 \%$ using a cut-off of $>95 \%$ [8]. This value was established by analysis of the area under the receiver operating characteristic curves, and had a maximum specificity (36\%) and sensitivity (91\%) to predict C-MYC breaks (area $=0.599,95 \%$ confidence interval $0.484-0.715, P=$ 0.063).

(d) From a practical point of view, we would recommend the following approach (Table 1):

- If c-myc is expressed in $\geq 40$ to $<75 \%$ and bcl 2 in $\geq 70 \%$ of tumor cells, it is classified as DLBCL with double hit score 2 (DHS-2).

- If c-myc is expressed in $>75 \%$ of tumor cells, FISH is recommended to identify $C-M Y C$ rearranged cases as well as to identify cases with c-myc upregulations resulting from mechanisms other than translocations. Only if $C-M Y C$ is rearranged and bcl 2 is expressed in $>70 \%$ of tumor cells is BCL2 FISH recommended, since double $B C L 2 / C-M Y C$ translocated cases (genotypic double-hits) have a very poor prognosis [53]. An additional BCL6 translocation does not seem to have a significant prognostic impact $[8,27]$, although this remains controversial $[54,55]$. Moreover, BCL6 is often found to be involved in so-called triple-hit lymphomas together with BCL2 and C-MYC translocations [42].

- If c-myc is expressed in 40 to $74 \%$ of the tumor cells, and $B C L 2$ in $<70 \%$, FISH can be omitted, since the probability of detecting rearranged $B C L 2$ is very low, and " $C-M Y C$-only" rearranged cases with low c-myc protein expression levels seem to have a prognosis similar to non-rearranged cases [8].

The main goal of this approach is the identification of patients who may benefit from different therapeutic strategies.
In the past, patients with $C-M Y C$ translocation did very poorly [38] with "CHOP-only" therapeutic regimens; while they improved with $\mathrm{R}-\mathrm{CHOP}$ regimens, the results are still poor compared to $C-M Y C$ unrearranged patients. Moreover, recent studies have shown that R-CHOP is not an optimal regimen for patients with phenotypic DHS 2 DLBCL, and is particularly inefficient in $C-M Y C / B C L 2$ genotypic double-hit DLBCL [56].

In the light of the favorable outcome of the $C$-MYC-driven $\mathrm{BL}$ and the impact of $C-M Y C$ on proliferation, it is appealing to consider the more aggressive therapies used in $\mathrm{BL}$ for this group of DLBCL patients. However, there is as yet no published data demonstrating that patients with "double-hit" DLBCL profit from more aggressive therapies [56]. Currently, the US Intergroup is studying a dose-adjusted R-EPOCH protocol (rituximab plus etoposide, prednisone, vincristine, cyclophosphamide, and doxorubicin) for $C$ - $M Y C$-driven DLBCL, including patients with double-hit biology. This regimen has shown efficacy in $\mathrm{BL}$ [57] and in isolated $C$ $M Y C$-rearranged cases, but not in genotypic double-hit DLBCL [55]. More importantly, the median age of these patients is 69 years, meaning that the majority will not be able to tolerate this regimen because of toxicity [55]. Therefore, while extremely promising, much work remains to be done toward the goal of improving the prognosis of these patients.

\section{B cell lymphoma, unclassified}

The current WHO classification system defines this category as a lymphoma that has both morphological and genetic features of DLBCL and BL, but cannot be decisively attributed to either disease entity. This includes morphology (cells not typical of BL) as well as immunohistochemistry (lacking the full BL phenotype) and genetics. $C-M Y C$ FISH is mandatory in this category, since $30-50 \%$ show a $C-M Y C$ gene translocation. Excluded from this category are typical $\mathrm{BL}$ without detectable $C$-MYC-rearrangement, phenotypic double-hit DLBCL, and otherwise clearly defined entities such as blastoid mantle cell lymphomas. However, according to the definition, transformed follicular lymphomas (FL) can also fall into this category [29], which is problematic since transformed FL are genetically and biologically different from aggressive lymphomas arising independently from underlying low-grade lymphomas. In contrast to de novo DLBCL, FL present with STAT6, ARIDIA, and FAS mutations and or deletions, as well as aberrations of MLL2, CREBBP, and $B C L 2$ [58]. Approximately $35-50 \%$ of these cases have $C$ $M Y C$ translocations, especially non- $I G / C-M Y C$ translocations [29].

According to the data of Hummel et al. [7], rare DLBCL $(7 / 114,6 \%)$ may show a true BL-signature on GEP and may be missed by the current definition based on morphology, 
immunohistochemistry, and FISH diagnostic/cytogenetics. Finally, there are cases classified as BL or BCL-U that lack $C$ $M Y C$-translocation but present with chromosome $11 \mathrm{q}$ aberrations, characterized by interstitial gains including 11q23.2q23.3 and telomeric losses of 11q24.1-qter [34], indicating a molecularly distinct subset of B cell lymphomas reminiscent of BL.

BCL-U are considered aggressive lymphomas with a shortened overall survival time [29, 59], and recent data suggests that $C-M Y C$ is most probably the main cause for this influence on prognosis, while BCL-U cases without C-MYC alterations do not differ from DLBCL cases [44]. Similar observations have been made in DLBCL based on expression of bcl 2 and cmyc, which abrogate the prognostic significance of the germinal center type/non-germinal center type DLBCL categories based on GEP data [28].

The central role of the $C-M Y C$ oncogene in the pathogenesis of aggressive lymphomas warrants further clinical research. However, the c-myc protein itself appears to be an undruggable target given that efforts to reduce $C-M Y C$ expression or interfere with its interaction partner, MAX, have not been successful to date. Novel approaches will target BRD4, a member of the bromodomain and extraterminal superfamily proteins (BET) [60, 61]. BRD4 regulates cmycexpression directly and indirectly via miRNA expression [62], and interference with BRD4 by small molecules (JQ1 and iBET) has shown significant downregulation of c-myc [63]. Such an interfering small molecule GSK525762 is currently being tested in a phase I study for relapsed hematologic diseases (NCT01943851). If the initial findings regarding $B R D 4$ and $C-M Y C$ can be translated into clinical practice, $C$ $M Y C$ status could become not only a prognostic, but also a predictive marker for BL, DLBCL, and other $C$-MYC-driven lymphoproliferative diseases, e.g., multiple myeloma and plasmablastic lymphoma.

\section{Conclusion}

The risk stratification of the clinically heterogeneous group of DLBCL is still ongoing. Recently, C-MYC and BCL2 have emerged as promising prognostic (immunohistochemical and genetic) markers that clearly stratify DLBCL patients into different risk groups. Unresolved issues include the fact that double-hit DLBCL (on the genetic level) and DHS 2 DLBCL (on the protein expression level) are not the same despite significant overlap between these two groups, and it remains to be determined whether risk stratification by FISH is superior to immunohistochemistry or vice versa. From our point of view, immunohistochemistry has advantages such as practicability, short turn-around time. and low cost, but FISH analysis remains an indispensable tool in some of the abovedescribed situations and cannot be completely replaced by immunohistochemistry. Considering that immunohistochemical stainings with the anti-c-myc antibody is a very recent methodology with limited experience, we recommend the use of a combined FISH and immunohistochemical model (Table 1). In light of the upcoming therapeutic options such as small molecules that downregulate $C-M Y C$, pathologies should be ready for adequate determination of $C-M Y C$ status.

Conflict of interest The authors declare that they have no conflict of interest.

\section{References}

1. Sheiness D, Fanshier L, Bishop JM (1978) Identification of nucleotide sequences which may encode the oncogenic capacity of avian retrovirus MC29. J Virol 28(2):600-610

2. Bister K, Jansen HW (1986) Oncogenes in retroviruses and cells: biochemistry and molecular genetics. Adv Cancer Res 47:99-188

3. Bishop JM (1982) Retroviruses and cancer genes. Adv Cancer Res 37:1-32

4. Meyer N, Penn LZ (2008) Reflecting on 25 years with MYC. Nat Rev Cancer 8(12):976-990

5. Pijnappel WW, Esch D, Baltissen MP, Wu G, Mischerikow N, Bergsma AJ et al (2013) A central role for TFIID in the pluripotent transcription circuitry. Nature 495(7442):516-519

6. Haralambieva E, Boerma EJ, van Imhoff GW, Rosati S, Schuuring E, Muller-Hermelink HK et al (2005) Clinical, immunophenotypic, and genetic analysis of adult lymphomas with morphologic features of Burkitt lymphoma. Am J Surg Pathol 29(8):1086-1094

7. Hummel M, Bentink S, Berger H, Klapper W, Wessendorf S, Barth $\mathrm{TF}$ et al (2006) A biologic definition of Burkitt's lymphoma from transcriptional and genomic profiling. N Engl J Med 354(23):24192430

8. Tzankov A, Xu-Monette ZY, Gerhard M, Visco C, Dirnhofer S, Gisin $\mathrm{N}$ et al (2014) Rearrangements of MYC gene facilitate risk stratification in diffuse large B-cell lymphoma patients treated with rituximab-CHOP. Mod Pathol Off J U S Can Acad Pathol Inc 27(7):958971

9. Klapper W, Stoecklein H, Zeynalova S, Ott G, Kosari F, Rosenwald A et al (2008) Structural aberrations affecting the MYC locus indicate a poor prognosis independent of clinical risk factors in diffuse large B-cell lymphomas treated within randomized trials of the German High-Grade Non-Hodgkin's Lymphoma Study Group (DSHNHL). Leukemia 22(12):2226-2229

10. Savage KJ, Johnson NA, Ben-Neriah S, Connors JM, Sehn LH, Farinha $P$ et al (2009) MYC gene rearrangements are associated with a poor prognosis in diffuse large B-cell lymphoma patients treated with R-CHOP chemotherapy. Blood 114(17):3533-3537

11. Alizadeh AA, Eisen MB, Davis RE, Ma C, Lossos IS, Rosenwald A et al (2000) Distinct types of diffuse large B-cell lymphoma identified by gene expression profiling. Nature 403(6769):503-511

12. Lenz G, Wright G, Dave SS, Xiao W, Powell J, Zhao H et al (2008) Stromal gene signatures in large-B-cell lymphomas. N Engl J Med 359(22):2313-2323

13. Pfreundschuh M (2012) Growing importance of MYC/BCL2 immunohistochemistry in diffuse large B-cell lymphomas. J Clin Oncol Off J Am Soc Clin Oncol 30(28):3433-3435

14. Hans CP, Weisenburger DD, Greiner TC, Gascoyne RD, Delabie J, Ott G et al (2004) Confirmation of the molecular classification of 
diffuse large B-cell lymphoma by immunohistochemistry using a tissue microarray. Blood 103(1):275-282

15. Muris JJ, Meijer CJ, Vos W, van Krieken JH, Jiwa NM, Ossenkoppele GJ et al (2006) Immunohistochemical profiling based on Bcl-2, CD10 and MUM1 expression improves risk stratification in patients with primary nodal diffuse large B cell lymphoma. J Pathol 208(5):714-723

16. Natkunam Y, Farinha P, Hsi ED, Hans CP, Tibshirani R, Sehn LH et al (2008) LMO2 protein expression predicts survival in patients with diffuse large B-cell lymphoma treated with anthracycline-based chemotherapy with and without rituximab. J Clin Oncol Off J Am Soc Clin Oncol 26(3):447-454

17. Nyman H, Jerkeman M, Karjalainen-Lindsberg ML, Banham AH, Leppa S (2009) Prognostic impact of activated B-cell focused classification in diffuse large B-cell lymphoma patients treated with RCHOP. Mod Pathol Off J U S Can Acad Pathol Inc 22(8):1094-1101

18. Choi WW, Weisenburger DD, Greiner TC, Piris MA, Banham AH, Delabie J et al (2009) A new immunostain algorithm classifies diffuse large B-cell lymphoma into molecular subtypes with high accuracy. Clin Cancer Res Off J Am Assoc Cancer Res 15(17):5494-5502

19. Meyer PN, Fu K, Greiner TC, Smith LM, Delabie J, Gascoyne RD et al (2011) Immunohistochemical methods for predicting cell of origin and survival in patients with diffuse large B-cell lymphoma treated with rituximab. J Clin Oncol Off J Am Soc Clin Oncol 29(2): 200-207

20. Visco C, Li Y, Xu-Monette ZY, Miranda RN, Green TM, Tzankov A et al (2012) Comprehensive gene expression profiling and immunohistochemical studies support application of immunophenotypic algorithm for molecular subtype classification in diffuse large B-cell lymphoma: a report from the International DLBCL RituximabCHOP Consortium Program Study. Leukemia 26(9):2103-2113

21. Gutierrez-Garcia G, Cardesa-Salzmann T, Climent F, GonzalezBarca E, Mercadal S, Mate JL et al (2011) Gene-expression profiling and not immunophenotypic algorithms predicts prognosis in patients with diffuse large B-cell lymphoma treated with immunochemotherapy. Blood 117(18):4836-4843

22. Thieblemont C, Briere J, Mounier N, Voelker HU, Cuccuini W, Hirchaud E et al (2011) The germinal center/activated B-cell subclassification has a prognostic impact for response to salvage therapy in relapsed/refractory diffuse large B-cell lymphoma: a bio-CORAL study. J Clin Oncol Off J Am Soc Clin Oncol 29(31):4079-4087

23. Gu K, Weisenburger DD, Fu K, Chan WC, Greiner TC, Aoun P et al (2012) Cell of origin fails to predict survival in patients with diffuse large B-cell lymphoma treated with autologous hematopoietic stem cell transplantation. Hematol Oncol 30(3):143-149

24. Green TM, Young KH, Visco C, Xu-Monette ZY, Orazi A, Go RS et al (2012) Immunohistochemical double-hit score is a strong predictor of outcome in patients with diffuse large B-cell lymphoma treated with rituximab plus cyclophosphamide, doxorubicin, vincristine, and prednisone. J Clin Oncol Off J Am Soc Clin Oncol 30(28): 3460-3467

25. Green TM, Nielsen O, de Stricker K, Xu-Monette ZY, Young KH, Moller MB (2012) High levels of nuclear MYC protein predict the presence of MYC rearrangement in diffuse large B-cell lymphoma. Am J Surg Pathol 36(4):612-619

26. Valera A, Lopez-Guillermo A, Cardesa-Salzmann T, Climent F, Gonzalez-Barca E, Mercadal S et al (2013) MYC protein expression and genetic alterations have prognostic impact in patients with diffuse large B-cell lymphoma treated with immunochemotherapy. Haematologica 98(10):1554-1562

27. Horn H, Ziepert M, Becher C, Barth TF, Bernd HW, Feller AC et al (2013) MYC status in concert with BCL2 and BCL6 expression predicts outcome in diffuse large B-cell lymphoma. Blood 121(12): 2253-2263

28. Hu S, Xu-Monette ZY, Tzankov A, Green T, Wu L, Balasubramanyam A et al (2013) MYC/BCL2 protein coexpression contributes to the inferior survival of activated B-cell subtype of diffuse large B-cell lymphoma and demonstrates high-risk gene expression signatures: a report from The International DLBCL Rituximab-CHOP Consortium Program. Blood 121(20):4021-4031, quiz 250

29. WHO Classification of Tumours of Haematopoietic and Lymphoid Tissues. Steven Swerdlow EC, Nancy Lee Harris, Elaine Jaffe, Stefano Pileri, Harald Stein, Jürgen Thiele, James Vardiman editor: IARC; 2008

30. Ruzinova MB, Caron T, Rodig SJ (2010) Altered subcellular localization of c-Myc protein identifies aggressive B-cell lymphomas harboring a c-MYC translocation. Am J Surg Pathol 34(6):882-891

31. Tapia G, Lopez R, Munoz-Marmol AM, Mate JL, Sanz C, Marginet $\mathrm{R}$ et al (2011) Immunohistochemical detection of MYC protein correlates with MYC gene status in aggressive B cell lymphomas. Histopathology 59(4):672-678

32. Oster SK, Mao DY, Kennedy J, Penn LZ (2003) Functional analysis of the N-terminal domain of the Myc oncoprotein. Oncogene 22(13): 1998-2010

33. Schraders M, de Jong D, Kluin P, Groenen P, van Krieken H (2005) Lack of Bcl-2 expression in follicular lymphoma may be caused by mutations in the BCL2 gene or by absence of the $t(14 ; 18)$ translocation. J Pathol 205(3):329-335

34. Salaverria I, Martin-Guerrero I, Wagener R, Kreuz M, Kohler CW, Richter J et al (2014) A recurrent 11q aberration pattern characterizes a subset of MYC-negative high-grade B-cell lymphomas resembling Burkitt lymphoma. Blood 123(8):1187-1198

35. Leucci E, Cocco M, Onnis A, De Falco G, van Cleef P, Bellan C et al (2008) MYC translocation-negative classical Burkitt lymphoma cases: an alternative pathogenetic mechanism involving miRNA deregulation. J Pathol 216(4):440-450

36. Kramer MH, Hermans J, Wijburg E, Philippo K, Geelen E, van Krieken JH et al (1998) Clinical relevance of BCL2, BCL6, and MYC rearrangements in diffuse large B-cell lymphoma. Blood 92(9): 3152-3162

37. Niitsu N, Okamoto M, Miura I, Hirano M (2009) Clinical features and prognosis of de novo diffuse large B-cell lymphoma with $\mathrm{t}(14 ; 18)$ and 8q24/c-MYC translocations. Leukemia 23(4):777-783

38. Obermann EC, Csato M, Dirnhofer S, Tzankov A (2009) Aberrations of the MYC gene in unselected cases of diffuse large B-cell lymphoma are rare and unpredictable by morphological or immunohistochemical assessment. J Clin Pathol 62(8):754-756

39. Yoon SO, Jeon YK, Paik JH, Kim WY, Kim YA, Kim JE et al (2008) MYC translocation and an increased copy number predict poor prognosis in adult diffuse large B-cell lymphoma (DLBCL), especially in germinal centre-like B cell (GCB) type. Histopathology 53(2):205-217

40. Johnson NA, Savage KJ, Ludkovski O, Ben-Neriah S, Woods R, Steidl C et al (2009) Lymphomas with concurrent BCL2 and MYC translocations: the critical factors associated with survival. Blood 114(11):2273-2279

41. Ueda C, Nishikori M, Kitawaki T, Uchiyama T, Ohno H (2004) Coexistent rearrangements of c-MYC, BCL2, and BCL6 genes in a diffuse large B-cell lymphoma. Int J Hematol 79(1):52-54

42. Aukema SM, Siebert R, Schuuring E, van Imhoff GW, KluinNelemans HC, Boerma EJ et al (2011) Double-hit B-cell lymphomas. Blood 117(8):2319-2331

43. Johnson NA, Slack GW, Savage KJ, Connors JM, Ben-Neriah S, Rogic S et al (2012) Concurrent expression of MYC and BCL2 in diffuse large B-cell lymphoma treated with rituximab plus cyclophosphamide, doxorubicin, vincristine, and prednisone. J Clin Oncol Off J Am Soc Clin Oncol 30(28):34523459

44. Cook JR, Goldman B, Tubbs RR, Rimsza L, Leblanc M, Stiff P et al (2014) Clinical significance of MYC expression and/or "high-grade" morphology in non-Burkitt, diffuse aggressive B-cell lymphomas: A SWOG S9704 correlative study. Am J Surg Pathol 38(4):494-501 
45. Munoz-Marmol AM, Sanz C, Tapia G, Marginet R, Ariza A, Mate JL (2013) MYC status determination in aggressive B-cell lymphoma: the impact of FISH probe selection. Histopathology 63(3):418-424

46. Kluk MJ, Chapuy B, Sinha P, Roy A, Dal Cin P, Neuberg DS et al (2012) Immunohistochemical detection of MYC-driven diffuse large B-cell lymphomas. PLoS One 7(4):e33813

47. Onnis A, De Falco G, Antonicelli G, Onorati M, Bellan C, Sherman $\mathrm{O}$ et al (2010) Alteration of microRNAs regulated by c-Myc in Burkitt lymphoma. PLoS One 5(9):e12960

48. Craig VJ, Cogliatti SB, Imig J, Renner C, Neuenschwander S, Rehrauer $\mathrm{H}$ et al (2011) Myc-mediated repression of microRNA34a promotes high-grade transformation of B-cell lymphoma by dysregulation of FoxP1. Blood 117(23):6227-6236

49. Stasik CJ, Nitta H, Zhang W, Mosher CH, Cook JR, Tubbs RR et al (2010) Increased MYC gene copy number correlates with increased mRNA levels in diffuse large B-cell lymphoma. Haematologica 95(4):597-603

50. Testoni M, Kwee I, Greiner TC, Montes-Moreno S, Vose J, Chan WC et al (2011) Gains of MYC locus and outcome in patients with diffuse large B-cell lymphoma treated with R-CHOP. Br J Haematol 155(2): 274-277

51. Zhou K, Xu D, Cao Y, Wang J, Yang Y, Huang M (2014) C-MYC aberrations as prognostic factors in diffuse large B-cell lymphoma: a meta-analysis of epidemiological studies. PLoS One 9(4):e95020

52. de Jong D, Xie W, Rosenwald A, Chhanabhai M, Gaulard P, Klapper $\mathrm{W}$ et al (2009) Immunohistochemical prognostic markers in diffuse large B-cell lymphoma: validation of tissue microarray as a prerequisite for broad clinical applications (a study from the Lunenburg Lymphoma Biomarker Consortium). J Clin Pathol 62(2):128-138

53. Barrans S, Crouch S, Smith A, Turner K, Owen R, Patmore R et al (2010) Rearrangement of MYC is associated with poor prognosis in patients with diffuse large B-cell lymphoma treated in the era of rituximab. J Clin Oncol Off J Am Soc Clin Oncol 28(20):3360-3365

54. Pillai RK, Sathanoori M, Van Oss SB, Swerdlow SH (2013) Double-hit B-cell lymphomas with BCL6 and MYC translocations are aggressive, frequently extranodal lymphomas distinct from BCL2 double-hit B-cell lymphomas. Am J Surg Pathol 37(3):323-332
55. Friedberg JW (2012) Double-hit diffuse large B-cell lymphoma. J Clin Oncol Off J Am Soc Clin Oncol 30(28):3439-3443

56. Friedberg JW, Unger JM, Burack WR, Gopal AK, Raju RN, Nademanee AP et al (2014) R-CHOP with iodine-131 tositumomab consolidation for advanced stage diffuse large B-cell lymphoma (DLBCL): SWOG S0433. Br J Haematol

57. Dunleavy K, Pittaluga S, Shovlin M, Steinberg SM, Cole D, Grant C et al (2013) Low-intensity therapy in adults with Burkitt's lymphoma. N Engl J Med 369(20):1915-1925

58. Pasqualucci L, Khiabanian H, Fangazio M, Vasishtha M, Messina M, Holmes AB et al (2014) Genetics of follicular lymphoma transformation. Cell Rep 6(1):130-140

59. Burgesser MV, Gualco G, Diller A, Natkunam Y, Bacchi CE (2013) Clinicopathological features of aggressive B-cell lymphomas including B-cell lymphoma, unclassifiable, with features intermediate between diffuse large B-cell and Burkitt lymphomas: a study of 44 patients from Argentina. Ann Diagn Pathol 17(3):250-255

60. Zuber J, Shi J, Wang E, Rappaport AR, Herrmann H, Sison EA et al (2011) RNAi screen identifies Brd4 as a therapeutic target in acute myeloid leukaemia. Nature 478(7370):524-528

61. Dawson MA, Prinjha RK, Dittmann A, Giotopoulos G, Bantscheff M, Chan WI et al (2011) Inhibition of BET recruitment to chromatin as an effective treatment for MLL-fusion leukaemia. Nature 478(7370):529-533

62. Delmore JE, Issa GC, Lemieux ME, Rahl PB, Shi J, Jacobs HM et al (2011) BET bromodomain inhibition as a therapeutic strategy to target c-Myc. Cell 146(6):904-917

63. Fowler T, Ghatak P, Price DH, Conaway R, Conaway J, Chiang CM et al (2014) Regulation of MYC expression and differential JQ1 sensitivity in cancer cells. PLoS One 9(1):e87003

64. Tzankov A, Zlobec I, Went P, Robl H, Hoeller S, Dirnhofer S (2010) Prognostic immunophenotypic biomarker studies in diffuse large B cell lymphoma with special emphasis on rational determination of cut-off scores. Leuk Lymphoma 51(2):199-212

65. Naresh KN, Ibrahim HA, Lazzi S, Rince P, Onorati M, Ambrosio MR et al (2011) Diagnosis of Burkitt lymphoma using an algorithmic approach - applicable in both resourcepoor and resource-rich countries. Br J Haematol 